\title{
Growth of Anodic Aluminum Oxide Templates and the Application in Fabrication of the BiSbTe-Based Thermoelectric Nanowires
}

\author{
Chin-Guo Kuo, ${ }^{1}$ Yuan-Tai Hsieh, ${ }^{2}$ Cheng-Fu Yang, ${ }^{3}$ Ching-Ho Huang, ${ }^{4}$ and Chia-Ying Yen ${ }^{1}$ \\ ${ }^{1}$ Department of Industrial Education, National Taiwan Normal University, Taipei 106, Taiwan \\ ${ }^{2}$ Department of Electronic Engineering, Southern Taiwan University, Tainan 710, Taiwan \\ ${ }^{3}$ Department of Chemical and Materials Engineering, National University of Kaohsiung, Kaohsiung 811, Taiwan \\ ${ }^{4}$ Taipei Municipal Nangang Vocational High School, Taipei 115, Taiwan \\ Correspondence should be addressed to Cheng-Fu Yang; cfyang@nuk.edu.tw
}

Received 13 January 2014; Revised 13 March 2014; Accepted 13 March 2014; Published 9 April 2014

Academic Editor: Ho Chang

Copyright (c) 2014 Chin-Guo Kuo et al. This is an open access article distributed under the Creative Commons Attribution License, which permits unrestricted use, distribution, and reproduction in any medium, provided the original work is properly cited.

\begin{abstract}
A two-step electrochemical anodization was used to form the anodic aluminum oxide (AAO) thin films with nanotube arrays of selforganized honeycomb structure. $\mathrm{Al}$ foil was anodized in $10 \%$ sulfuric acid $\left(\mathrm{H}_{2} \mathrm{SO}_{4}\right)$ and $3 \%$ oxalic acid $\left(\mathrm{H}_{2} \mathrm{C}_{2} \mathrm{O}_{4}\right)$ at $25^{\circ} \mathrm{C}$ at constant voltage of $40 \mathrm{~V}$ for $60 \mathrm{~min}$ for two times. Ethylene glycol $\left(\mathrm{C}_{2} \mathrm{H}_{6} \mathrm{O}_{2}\right)$ was used as a solution and $0.3 \mathrm{M}$ potassium iodide (KI) was used to improve the solution's conductivity. Different electrolyte concentrations of $\mathrm{Bi}\left(\mathrm{NO}_{3}\right)_{3}-5 \mathrm{H}_{2} \mathrm{O}, \mathrm{SbCl}_{3}$, and $\mathrm{TeCl} \mathrm{Cl}_{4}$ were added into $\mathrm{KI}-\mathrm{C}_{2} \mathrm{H}_{6} \mathrm{O}_{2}$ solution and the cyclic voltammetry experiment was used to find the reduced voltages of $\mathrm{Bi}^{3+}, \mathrm{Sb}^{3+}$, and $\mathrm{Te}^{4+}$ ions. The potentiostatic deposition and pulse electrodeposition (PED) processes were used to deposit the (Bi,Sb) ${ }_{2-x} \mathrm{Te}_{3+x}$-based materials. Field-emission scanning electron microscope and energy dispersive spectrometers were used to analyze the compositions of the deposited $(\mathrm{Bi}, \mathrm{Sb})_{2-x} \mathrm{Te}_{3+x}$-based materials. After finding the optimal deposition parameter of the PED process the AAO nanotube arrays were used as the templates to deposit the $(\mathrm{Bi}, \mathrm{Sb})_{2-x} \mathrm{Te}_{3+x}$-based thermoelectric nanowires.
\end{abstract}

\section{Introduction}

Thermoelectric energy conversion has attracted much interest as a possible application for environmentally friendly electric-power generators and highly reliable, accurate temperature controllable refrigerators used as electronic devices because it is one of the simplest technologies applicable to energy conversion [1-4]. The efficiency of thermoelectricity is governed by a basic property of thermoelectric material, and the figure of merit of a thermoelectric material is defined by

$$
Z T=\frac{S^{2} T \delta}{\left(\kappa_{e}+\kappa_{l}\right)}
$$

where $T$ is the absolute temperature. As (1) shows, optimally thermoelectric materials will have high electrical conductivity $(\delta)$, low thermal conductivity (the electron thermal conductivity $\kappa_{e}$ and the lattice thermal conductivity $\kappa_{l}$ ), and high thermoelectric power ( $S$, Seebeck coefficient). For a material to be good in thermoelectric application, it must have a high thermoelectric figure of merit ZT. Much of the recent work on thermoelectric materials has focused on the ability of heterostructures and quantum confinement to increase efficiency over bulk materials [5-7].

So far, the thermoelectric materials used in applications have all been in bulk (3D) and thin film (2D) forms. However, Hicks and Dresselhaus had pointed out that low-dimensional materials have better efficiency than bulk ones due to low-dimensional effects on both charge carriers and lattice waves [8]. However, since the 1960s only slow progress has been made in enhancing $Z T$ [9], either in $(\mathrm{Bi}, \mathrm{Sb})_{2-x} \mathrm{Te}_{3+x}$-based alloys or in other thermoelectric material. The validity of attaining higher $Z T$ value in lowdimensional systems has been experimentally demonstrated on $\mathrm{Bi}_{2} \mathrm{Te}_{3} / \mathrm{Sb}_{2} \mathrm{Te}_{3}$ superlattices [10] and on $\mathrm{PbTe} / \mathrm{PbSeTe}$ 


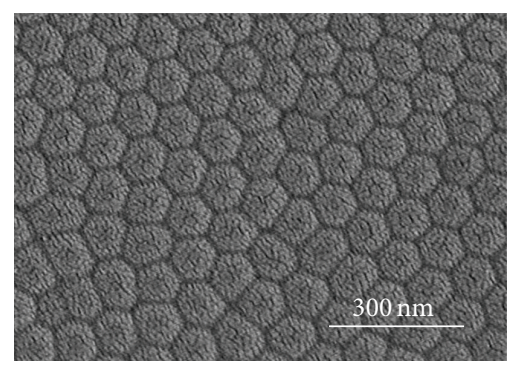

(a)

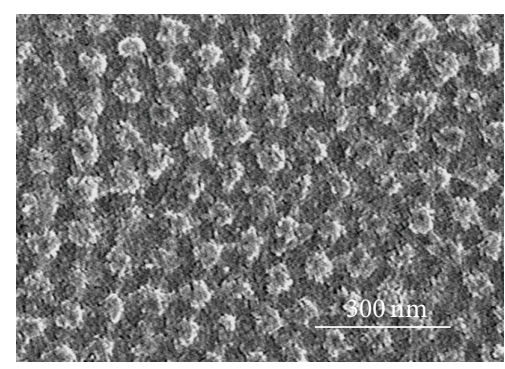

(b)

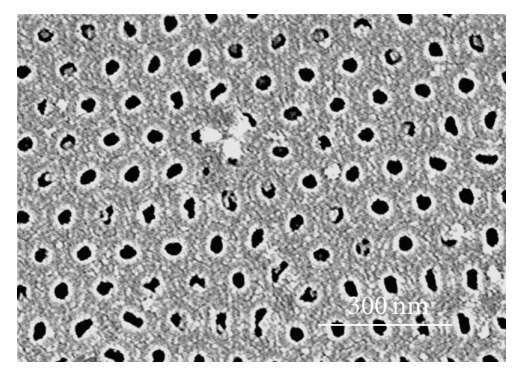

(c)

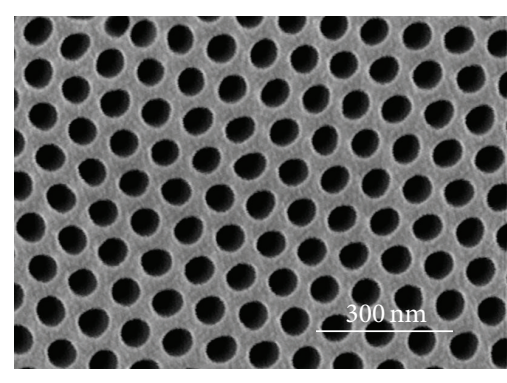

(d)

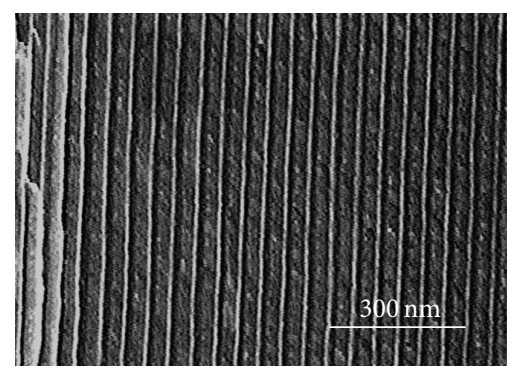

(e)

Figure 1: $3 \mathrm{wt} \%-\mathrm{KOH}$ was used to remove the barrier layer as a function of etched time: (a) $0 \mathrm{~min}$, (b) $3 \mathrm{~min}$, (c) $6 \mathrm{~min}$, and (d) $7.5 \mathrm{~min}$, respectively, and (e) side view of nanotubes.

quantum dots [11] with $Z T \sim 2.4$ and 1.6, respectively, at $300 \mathrm{~K}$. Therefore, nanowires are potentially structured to get good thermoelectrical systems for application. In the past, electrochemical deposition was a useful method to deposit the thin films in different morphologies, including thin films and nanowires [12]. Various techniques, including chemical vapor deposition [10], molecular beam epitaxy [13], vaporliquid-solid growth process [14], and hydrothermal process [15], have been applied to synthesize thin film-, nanowire-, or nanotube-structured thermoelectric materials. Compared to those methods, electrodeposition is one the most costeffective techniques to fabricate the nanostructured materials [16]. Bismuth telluride- $\left(\mathrm{Bi}_{2} \mathrm{Te}_{3}{ }^{-}\right)$[17] and $(\mathrm{Bi}, \mathrm{Sb})_{2} \mathrm{Te}_{3}{ }^{-}$ based alloys [18] are very attractive thermoelectric (TE) materials due to their high energy conversion efficiency at ambient temperature for achieving power generation without requiring any driving parts or cooling systems in electronic devices. In this study, we tried to investigate a new method for fabrication of the $(\mathrm{Bi}, \mathrm{Sb})_{2-x} \mathrm{Te}_{3+x}$-based thermoelectric materials with one-dimension (1D) structure. Anodic aluminum oxide (AAO) thin films with the nanotube structure were used as template to fabricate the $(\mathrm{Bi}, \mathrm{Sb})_{2-x} \mathrm{Te}_{3+x}$-based nanowires. At first, ethylene glycol $\left(\mathrm{C}_{2} \mathrm{H}_{6} \mathrm{O}_{2}\right)$ was used as the solution and $0.3 \mathrm{M}$ potassium iodide $(\mathrm{KI})$ was added to improve the conductivity of the solution. Electrolyte formulas with different concentrations of $\mathrm{Bi}\left(\mathrm{NO}_{3}\right)_{3}-5 \mathrm{H}_{2} \mathrm{O}, \mathrm{SbCl}_{3}$, and $\mathrm{TeCl}_{4}$ were used to find the effects of ionic concentrations on the composition fluctuation of the reduced $(\mathrm{Bi}, \mathrm{Sb})_{2-x} \mathrm{Te}_{3+x^{-}}$ based materials by using the potentiostatic deposition process. Finally, the ethylene glycol solution contains $0.015 \mathrm{M}$ $\mathrm{Bi}\left(\mathrm{NO}_{3}\right)_{3}-5 \mathrm{H}_{2} \mathrm{O}, 0.005 \mathrm{M} \mathrm{SbCl}_{3}$, and $0.0075 \mathrm{M} \mathrm{TeCl}_{4}$ and was used to deposit $(\mathrm{Bi}, \mathrm{Sb})_{2-x} \mathrm{Te}_{3+x}$-based nanowires in $\mathrm{AAO}$ templates by means of the pulse electrodeposition (PED) process.

\section{Experimental Details}

For the AAO templates, annealed high-purity (99.99\%) aluminum foil was electropolished in a mixture of $\mathrm{HClO}_{4}$ (25\% in volume ratio) and $\mathrm{C}_{2} \mathrm{H}_{5} \mathrm{OH}(75 \%)$ until the rootmean-square surface roughness of a typical $10 \mu \mathrm{m} \times 10 \mu \mathrm{m}$ area was $1 \mathrm{~nm}$. In this study a two-step electrochemical anodization was used to form the AAO template [19]. For the first anodization process, the foil was anodized in $10 \%$ sulfuric acid $\left(\mathrm{H}_{2} \mathrm{SO}_{4}\right)$ and $3 \%$ oxalic acid $\left(\mathrm{H}_{2} \mathrm{C}_{2} \mathrm{O}_{4}\right)$ at $25^{\circ} \mathrm{C}$ at constant voltage of $40 \mathrm{~V}$ for $5 \mathrm{~h}$, for that the AAO substrates with nanotube arrays of self-organized honeycomb structure were obtained. Then the semifinished AAO templates were produced and subsequently the thick oxide was stripped away by immersing the AAO samples in a mixture containing $2 \mathrm{wt} \%$ chromic acid and $6 \mathrm{wt} \%$ phosphoric acid at $60^{\circ} \mathrm{C}$. The second anodization process, which was similar to the first stage, was carried out until the remaining Al sample was completely anodized, and the finished AAO templates were thus fabricated [20]. Nevertheless, we further widened the pores of AAO templates by using a $5 \mathrm{wt} \%$ phosphoric acid solution at $25^{\circ} \mathrm{C}$ for $30 \mathrm{~min}$. The cylindrical nanotubes penetrated the entire thickness of the AAO templates. As Figure 1(a) shows, the hole diameter of each pore was approximately $70 \mathrm{~nm}$ and the pitch between one neighboring pores, as Figure 1(b) shows, was about $100 \mathrm{~nm}$. In order to deposit the $(\mathrm{Bi}, \mathrm{Sb})_{2-x} \mathrm{Te}_{3+x}$-based nanowires the barrier layer between the AAO nanotubes and Al plate should be removed. 
The $3 \mathrm{wt} \%-\mathrm{KOH}$ was used as the etched electrolyte solution; Figures $1(\mathrm{a})-1(\mathrm{~d})$ show the effect of the $\mathrm{KOH}$-etched time; $7.5 \mathrm{~min}$ was enough to remove barrier layer. For that, the cylindrical nanotubes penetrated the entire thickness of the AAO templates; as Figure 1(e) shows, the hole diameter of each tube was approximately $60 \sim 65 \mathrm{~nm}$ and the hole wall of each tube was around $35 \sim 40 \mathrm{~nm}$.

In the conventional direct current (DC) plating, only one parameter of current density (I) can be varied. But in pulse electrodeposition (PED) process three independent variables, including (a) on time $\left(T_{\text {on }}\right)$, (b) off time $\left(T_{\text {off }}\right)$, and (c) peak current density (IP), can be used as the independent variables. For that, the PED process was used to deposit the $(\mathrm{Bi}, \mathrm{Sb})_{2-x} \mathrm{Te}_{3+x}$-based thermoelectric nanomaterials and nanowires. In pulse current (PC), the duty cycle corresponding to the percentage of total time of a cycle is given by [21]

$$
\text { Duty cycle }=\frac{T_{\text {on }}}{\left(T_{\text {off }}+T_{\text {on }}\right)}=T_{\text {on } f} \text {, }
$$

where $f$ is frequency, defined as the reciprocal of the cycle time. That is,

$$
\text { Frequency }(f)=\frac{1}{\left(T_{\text {off }}+T_{\text {on }}\right)}=\frac{1}{T} \text {. }
$$

PC will deposit metal at the same rate as the provided DC average pulse current density equals the latter. The average current density (IA), in pulse plating, is defined as

$$
\text { IA = peak current }(\text { IP }) \times \text { duty cycle } .
$$

The successfully practical applications of the nanostructured thermoelectric devices must investigate a costeffective and high throughput fabrication process. At first, potentiostatic deposition process was used as the deposition process, ethylene glycol $\left(\mathrm{C}_{2} \mathrm{H}_{6} \mathrm{O}_{2}\right)$ was used as a solution, and $0.3 \mathrm{M}$ potassium iodide $(\mathrm{KI})$ was added to improve the conductivity of the solution. $\mathrm{Bi}\left(\mathrm{NO}_{3}\right)_{3}-5 \mathrm{H}_{2} \mathrm{O}, \mathrm{SbCl}_{3}$, and $\mathrm{TeCl}_{4}$ were used as the electrolyte sources. The effect of electrolyte concentrations on the compositions of the deposited $(\mathrm{Bi}, \mathrm{Sb})_{2-x} \mathrm{Te}_{3+x}$-based materials was investigated. Next, the duration of $T_{\text {off }}$ ( $T_{\text {on }}$ was set at $0.2 \mathrm{~s}$ ) and the reduced voltage during the duration of $T_{\text {on }}$ were changed to find the optimal deposition parameters to get the $(\mathrm{Bi}, \mathrm{Sb})_{2-x} \mathrm{Te}_{3+x^{-}}$ based materials with $(\mathrm{Bi}+\mathrm{Sb}) / \mathrm{Te}$ atomic ratio close to $2 / 3$. Finally, deposition of $(\mathrm{Bi}, \mathrm{Sb})_{2-x} \mathrm{Te}_{3+x}$-based nanowires in AAO templates was investigated by means of pulse deposition process by using the ethylene glycol solution containing $0.015 \mathrm{M} \mathrm{Bi}\left(\mathrm{NO}_{3}\right)_{3}-5 \mathrm{H}_{2} \mathrm{O}, 0.005 \mathrm{M} \mathrm{SbCl}_{3}, 0.0075 \mathrm{M} \mathrm{TeCl}_{4}$, and $0.3 \mathrm{M}$ KI. The field-emission scanning electron microscope (FESEM) and energy dispersive spectrometers (EDS) were used to observe the morphology and analyze the composition of the deposited $(\mathrm{Bi}, \mathrm{Sb})_{2-x} \mathrm{Te}_{3+x}$ materials and nanowires.

\section{Results and Discussion}

At first, we used the cyclic voltammetry experiment to find the optimally reduced voltages of $\mathrm{Bi}^{3+}, \mathrm{Sb}^{3+}$, or $\mathrm{Te}^{4+}$ ions, respectively. The working electrode potential was linearly

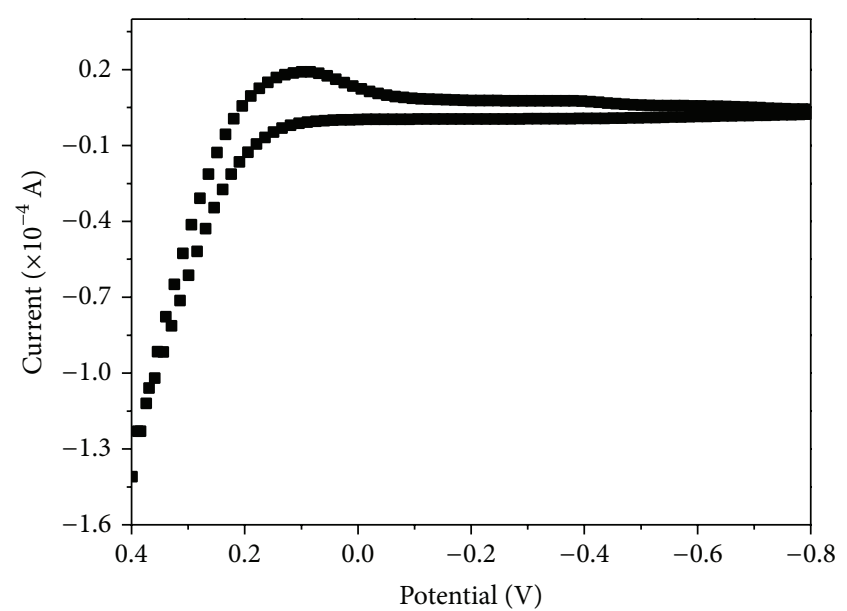

FIGURE 2: Cyclic voltammetry curve of the $0.3 \mathrm{M}$ KI in ethylene glycol.

ramped versus time like linear sweep voltammetry, and the experiment's scan rate was $10 \mathrm{mV} / \mathrm{sec}$ and the scan range is $0.4 \mathrm{~V}$ to $-0.7 \mathrm{~V}$. If only pure ethylene glycol $\left(\mathrm{C}_{2} \mathrm{H}_{6} \mathrm{O}_{2}\right)$ was used as analyte, the current peak for the reduced and oxidized reactions was not observed (not shown here). If only $0.3 \mathrm{M} \mathrm{KI}$ was added into $\mathrm{C}_{2} \mathrm{H}_{6} \mathrm{O}_{2}$ as electrolyte, the current peak for the reduced and oxidized reactions was not observed in the range of $0.20 \mathrm{~V}$ to $-0.70 \mathrm{~V}$ (not shown here). As the voltage was in the range of $0.20 \mathrm{~V}$ to $0.40 \mathrm{~V}$, the oxidized current increased, as Figure 2 shows. Those results prove that the ethylene glycol is used as the solvent, KI can be added to improve the conductivity, and they will not influence the results of the cyclic voltammetry deposition. And next, $0.01 \mathrm{M} \mathrm{Bi}\left(\mathrm{NO}_{3}\right)_{3}-5 \mathrm{H}_{2} \mathrm{O}, 0.01 \mathrm{M} \mathrm{SbCl}_{3}$, and $0.01 \mathrm{M}$ $\mathrm{TeCl}_{4}$ each alone was added and pure ethylene glycol was used as analyte. The reduced reactions found that starting reduction voltages of $\mathrm{Bi}^{3+}, \mathrm{Sb}^{3+}$, and $\mathrm{Te}^{4+}$ ions were $-0.23 \mathrm{~V}$, $-0.23 \mathrm{~V}$, and $0.20 \mathrm{~V}$, respectively (not shown here). The results of the cyclic voltammetry curves suggest that $\mathrm{Te}^{4+}$ will be the first ions being reduced into metal.

If $0.01 \mathrm{M} \mathrm{Bi}\left(\mathrm{NO}_{3}\right)_{3}-5 \mathrm{H}_{2} \mathrm{O}$ and $0.01 \mathrm{M} \mathrm{TeCl}_{4}$ were coadded in pure ethylene glycol, the cyclic voltammetry curve was as shown in Figure 3; if $0.01 \mathrm{M} \mathrm{Bi}\left(\mathrm{NO}_{3}\right)_{3}-5 \mathrm{H}_{2} \mathrm{O}, 0.01 \mathrm{M} \mathrm{SbCl}_{3}$, and $0.01 \mathrm{M} \mathrm{TeCl}_{4}$ were all added in pure ethylene glycol, the cyclic voltammetry curve was as shown in Figure 4 . The first reduced reaction in Figures 3 and 4 started at around $0.2 \mathrm{~V}$. From the results of using $0.01 \mathrm{M} \mathrm{Bi}\left(\mathrm{NO}_{3}\right)_{3}-5 \mathrm{H}_{2} \mathrm{O}, 0.01 \mathrm{M}$ $\mathrm{SbCl}_{3}$, and $0.01 \mathrm{M} \mathrm{TeCl}_{4}$ each alone we can confirm that is the reduction process of the $\mathrm{Te}^{4+}$ ions. Those results suggest that, as large negative voltage was used as the reduced voltage, the deposited compositions are composed of $\mathrm{Bi}, \mathrm{Sb}$, and $\mathrm{Te}$. The reduction of $\mathrm{Bi}^{3+}, \mathrm{Sb}^{3+}$, and $\mathrm{Te}^{4+}$ ions is not unique; they cannot be reduced alone by electrodeposition but can be reduced when codeposited with other elements, defined as induced codeposition. As ethylene glycol is used as analyte, the induced codeposition process, which is found in using water as analyte, will not happen. The large difference in the 
TABLE 1: Effects of deposition voltage on the composition of the $(\mathrm{Bi}, \mathrm{Sb})_{2-x} \mathrm{Te}_{3+x}$-based materials; the deposition time was 60 min. Electrolyte formula was (a) $0.03 \mathrm{M} \mathrm{Bi}\left(\mathrm{NO}_{3}\right)_{3}-5 \mathrm{H}_{2} \mathrm{O}$ and $0.04 \mathrm{M} \mathrm{TeCl}_{4}$ (b) $0.01 \mathrm{M} \mathrm{Bi}\left(\mathrm{NO}_{3}\right)_{3}-5 \mathrm{H}_{2} \mathrm{O}, 0.01 \mathrm{M} \mathrm{SbCl}_{3}$, and $0.01 \mathrm{M} \mathrm{TeCl}_{4}$, respectively.

\begin{tabular}{|c|c|c|c|c|c|}
\hline \multirow{2}{*}{$\begin{array}{l}\text { Compositions } \\
\text { Potential (V) }\end{array}$} & \multicolumn{2}{|c|}{$0.03 \mathrm{M} \mathrm{Bi}\left(\mathrm{NO}_{3}\right)_{3}-5 \mathrm{H}_{2} \mathrm{O}$ and $0.04 \mathrm{M} \mathrm{TeCl}_{4}$} & \multicolumn{3}{|c|}{$0.01 \mathrm{M} \mathrm{Bi}\left(\mathrm{NO}_{3}\right)_{3}-5 \mathrm{H}_{2} \mathrm{O}, 0.01 \mathrm{M} \mathrm{SbCl}_{3}$, and $0.01 \mathrm{M} \mathrm{TeCl}_{4}$} \\
\hline & $\mathrm{Te}$ & $\mathrm{Bi}$ & $\mathrm{Sb}$ & $\mathrm{Te}$ & $\mathrm{Bi}$ \\
\hline $0.0 \mathrm{~V}$ & & & 0 & 94.5 & 5.5 \\
\hline$-0.2 \mathrm{~V}$ & 61.855 & 38.15 & 5.32 & 89.22 & 5.54 \\
\hline$-0.3 \mathrm{~V}$ & 63.48 & 36.52 & 37.35 & 44.05 & 18.61 \\
\hline$-0.4 \mathrm{~V}$ & 56.94 & 43.07 & 36.23 & 44.01 & 19.78 \\
\hline$-0.5 \mathrm{~V}$ & 64.1 & 35.9 & 41.42 & 33.72 & 24.86 \\
\hline$-0.6 \mathrm{~V}$ & 70.23 & 29.77 & 45.15 & 44.75 & 10.11 \\
\hline
\end{tabular}

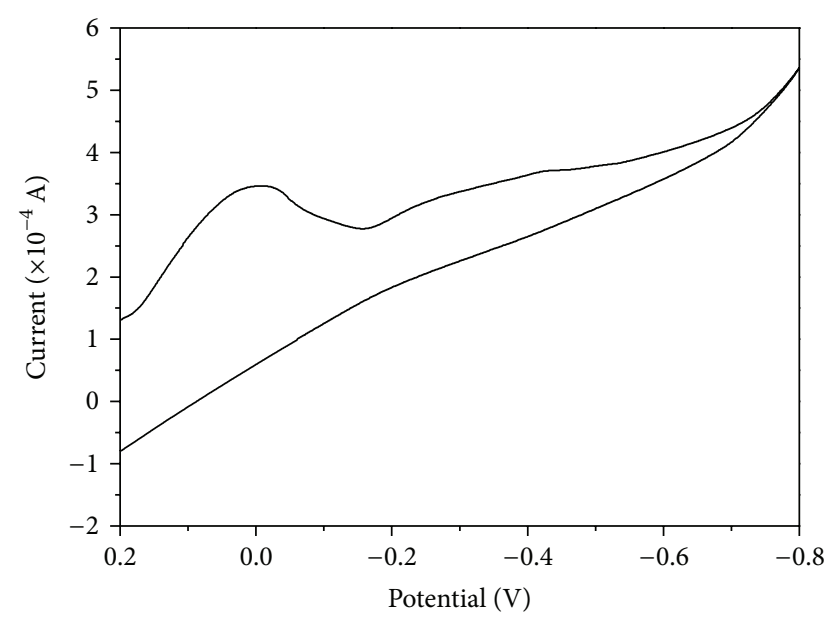

FIGURE 3: Cyclic voltammetry curve of $0.3 \mathrm{M} \mathrm{KI}, 0.01 \mathrm{M} \mathrm{Bi}^{3+}$, and $0.01 \mathrm{M} \mathrm{Te}^{4+}$ in ethylene glycol.

reduced voltages of $\mathrm{Bi}^{3+}, \mathrm{Sb}^{3+}$, and $\mathrm{Te}^{4+}$ ions will cause this result.

When more than two different ions exist in the analyte and the cyclic voltammetry process under different reduced voltage is used, the obtained metallic compounds have different compositions. For that, the potentiostatic deposition process was used to deposit the $(\mathrm{Bi}, \mathrm{Sb})_{2-x} \mathrm{Te}_{3+x}$-based materials. FESEM observation on the surface morphology and EDS analyses on the composition of the deposited $(\mathrm{Bi}, \mathrm{Sb})_{2-x} \mathrm{Te}_{3+x}$-based materials were used to find the relationships between the deposition voltage and the deposition compositions. Table 1 shows the effects of different deposition voltage and different electrolyte formula on the composition of the deposited $(\mathrm{Bi}, \mathrm{Sb})_{2-x} \mathrm{Te}_{3+x}$-based materials, and deposition time is $60 \mathrm{~min}$.

At first, $0.03 \mathrm{M} \mathrm{Bi}\left(\mathrm{NO}_{3}\right)_{3}-5 \mathrm{H}_{2} \mathrm{O}$ and $0.04 \mathrm{M} \mathrm{TeCl}_{4}$ were used as the electrolyte formulas to find the variation in the composition of the deposited $\mathrm{Bi}_{2-x} \mathrm{Te}_{3+x}$-based materials. The results in Table 1 show that, as reduced voltage was changed from $-0.2 \mathrm{~V}$ to $-0.6 \mathrm{~V}$, the $\mathrm{Bi} /$ Te ratio first increased, reached a maximum value at $-0.4 \mathrm{~V}$, and then decreased with further increasing of reduced voltage. However, as the voltage was in the range of $-0.2 \mathrm{~V}$ to $-0.5 \mathrm{~V}$, the composition of the deposited $\mathrm{Bi}_{2-x} \mathrm{Te}_{3+x}$-based materials was close to $\mathrm{Bi} / \mathrm{Te}=2 / 3$

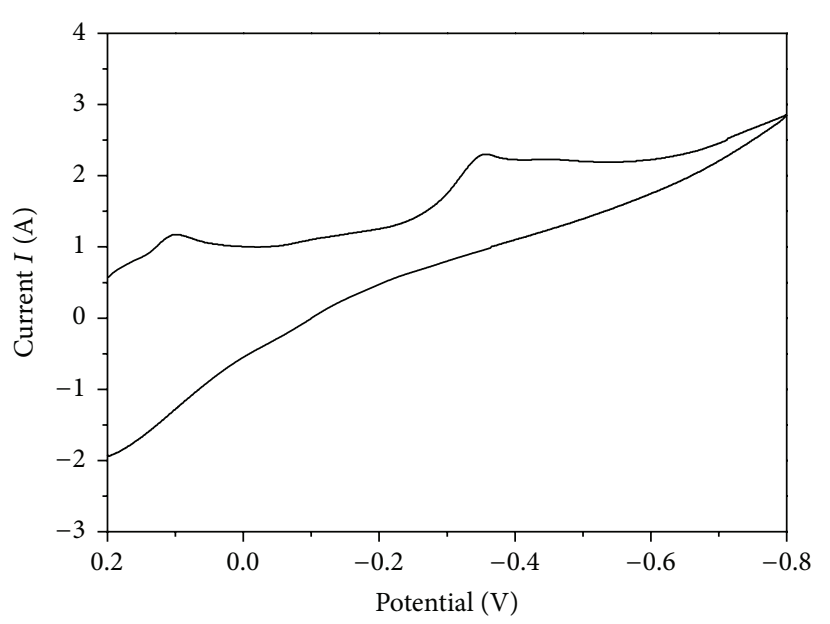

Figure 4: Cyclic voltammetry curve of $0.3 \mathrm{M} \mathrm{KI}, 0.01 \mathrm{M} \mathrm{Bi}^{3+}, 0.01 \mathrm{M}$ $\mathrm{Sb}^{3+}$, and $0.01 \mathrm{M} \mathrm{Te}^{4+}$ in ethylene glycol.

$\left(\mathrm{Bi}_{2} \mathrm{Te}_{3}\right)$. When the electrolyte formula of $0.01 \mathrm{M} \mathrm{Bi}\left(\mathrm{NO}_{3}\right)_{3}-$ $5 \mathrm{H}_{2} \mathrm{O}, 0.01 \mathrm{M} \mathrm{SbCl}_{3}$, and $0.01 \mathrm{M} \mathrm{TeCl}_{4}$ was used, as Table 1 shows, as the voltage was $0.0 \mathrm{~V}$ to $-0.2 \mathrm{~V}$, the main element was $\mathrm{Te}$. The $(\mathrm{Bi}, \mathrm{Sb})_{2-x} \mathrm{Te}_{3+x}$ composition was obtained as the voltage was in the range of $-0.30 \mathrm{~V}$ to $-0.60 \mathrm{~V}$.

The results in Table 1 reveal that the electrolyte formula and the deposition voltage are the two important parameters to influence the composition of the deposited $(\mathrm{Bi}, \mathrm{Sb})_{2-x} \mathrm{Te}_{3+x}$-based materials. Table 1 also shows that, as the reduced voltage is changed from $0.00 \mathrm{~V}$ to $-0.50 \mathrm{~V}$, the concentrations of $\mathrm{Bi}$ and $\mathrm{Sb}$ increase; two reasons are believed to cause this result. First, the reduced reactions of $\mathrm{Bi}^{3+}$, $\mathrm{Sb}^{3+}$, and $\mathrm{Te}^{4+}$ start at $-0.23 \mathrm{~V},-0.23 \mathrm{~V}$, and $0.20 \mathrm{~V}$. For that, as $0.00 \mathrm{~V}$ to $-0.20 \mathrm{~V}$ is used, the main element in the deposited materials is Te. As the voltage is equal to and smaller than $-0.30 \mathrm{~V}$, the driving forces of reduction for $\mathrm{Bi}$ and $\mathrm{Sb}$ increase and the concentrations of $\mathrm{Bi}$ and $\mathrm{Sb}$ in the deposited materials increase. Second, the driving force for mass transfer is typical difference in chemical potential, though other thermodynamic gradients may couple with the flow of mass and drive it as well. As the voltage value is more negative (means the applied voltage is larger than the needed reduction voltage), the mass transfer effect will influence the composition of the deposited $(\mathrm{Bi}, \mathrm{Sb})_{2-x} \mathrm{Te}_{3+x}$ 


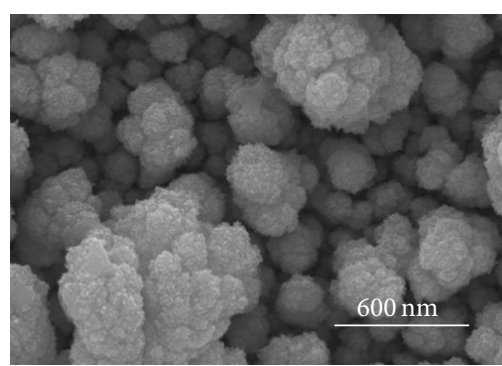

(a)

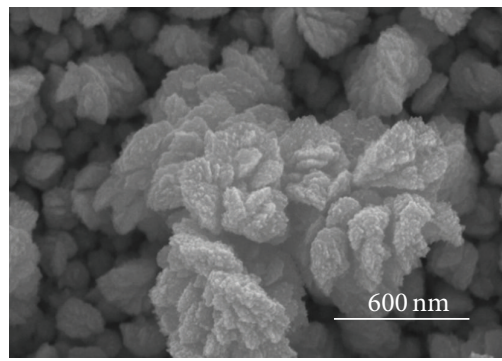

(d)

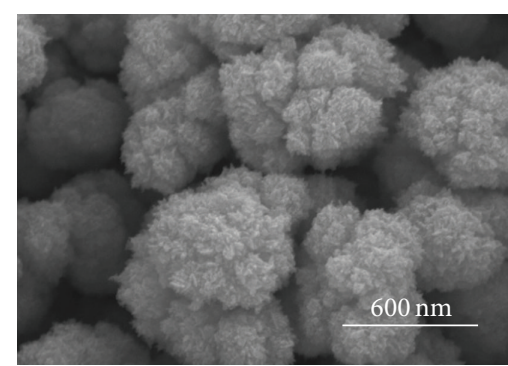

(b)

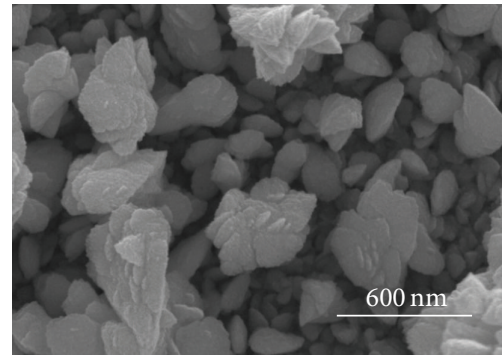

(e)

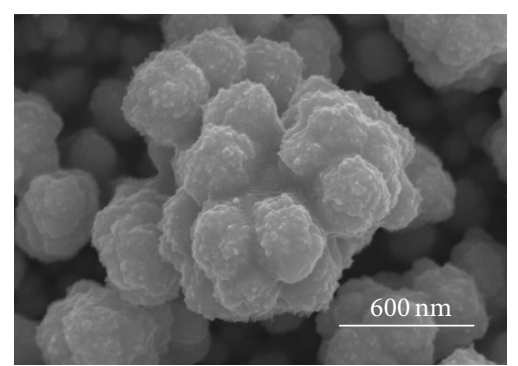

(c)

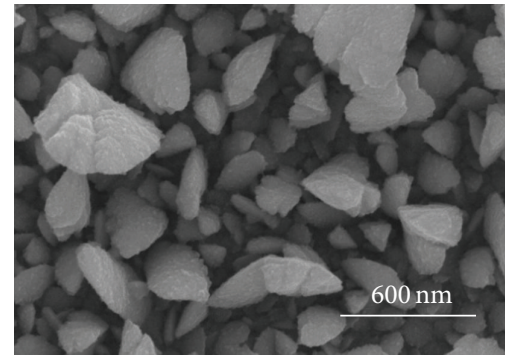

(f)

FIGURE 5: SEM micrographs of the electrolyte formula $0.015 \mathrm{M} \mathrm{Bi}\left(\mathrm{NO}_{3}\right)_{3}-5 \mathrm{H}_{2} \mathrm{O}, 0.005 \mathrm{M} \mathrm{SbCl}_{3}$, and $0.0075 \mathrm{M} \mathrm{TeCl}_{4}$; pulse voltage was set at $-0.4 \mathrm{~V}, T_{\text {on }}$ was set at $0.2 \mathrm{~s}$, and $T_{\text {off }}$ was changed: (a) $T_{\text {off }}=0.1 \mathrm{~s}$, (b) $T_{\text {off }}=0.4 \mathrm{~s}$, (c) $T_{\text {off }}=1 \mathrm{~s}$, (d) $T_{\text {off }}=1.6 \mathrm{~s},(\mathrm{e}) T_{\text {off }}=2 \mathrm{~s}$, and (f) $T_{\text {off }}=4 \mathrm{~s}$.

TABLE 2: Effects of pulse deposition parameters on the composition of the (Bi,Sb) ${ }_{2-x} \mathrm{Te}_{3+x}$ materials; (a) the bias voltage was set at $-0.4 \mathrm{~V}, T_{\text {on }}$ was set at $0.2 \mathrm{~s}$, and $T_{\text {off }}$ was changed from $0.1 \mathrm{~s}$ to $4 \mathrm{~s}$. (b) $T_{\text {on }}$ and $T_{\text {off }}$ were set at $0.2 \mathrm{~s}$ and $1 \mathrm{~s}$, and the pulse voltage was changed.

\begin{tabular}{|c|c|c|c|c|c|c|c|}
\hline \multirow{2}{*}{ Different $T_{\text {off }}$} & \multicolumn{3}{|c|}{ Pulse (voltage $\left.=-0.4 \mathrm{~V}, T_{\text {on }}=0.2 \mathrm{~s}\right)$} & \multirow{2}{*}{ Different voltage $(\mathrm{V})$} & \multicolumn{3}{|c|}{ Pulse $\left(T_{\text {on }}=0.2 \mathrm{~s}, T_{\text {off }}=1 \mathrm{~s}\right)$} \\
\hline & $\mathrm{Sb}$ & $\mathrm{Te}$ & $\mathrm{Bi}$ & & $\mathrm{Sb}$ & $\mathrm{Te}$ & $\mathrm{Bi}$ \\
\hline$T_{\text {off }}=0.1 \mathrm{~s}$ & 7.09 & 31.29 & 61.63 & $0.0 \mathrm{~V}$ & - & - & - \\
\hline$T_{\text {off }}=0.4 \mathrm{~s}$ & 7.71 & 41.05 & 51.25 & $-0.2 \mathrm{~V}$ & - & - & - \\
\hline$T_{\text {off }}=1 \mathrm{~s}$ & 12.02 & 69.43 & 18.54 & $-0.3 \mathrm{~V}$ & 27.16 & 66.60 & 5.59 \\
\hline$T_{\text {off }}=1.6 \mathrm{~s}$ & 7.22 & 79.62 & 13.16 & $-0.4 \mathrm{~V}$ & 32.88 & 56.95 & 10.17 \\
\hline$T_{\text {off }}=2 \mathrm{~s}$ & 5.77 & 84.06 & 10.17 & $-0.5 \mathrm{~V}$ & 24.38 & 56.13 & 19.49 \\
\hline$T_{\text {off }}=4 \mathrm{~s}$ & 6.24 & 86.30 & 7.46 & $-0.6 \mathrm{~V}$ & 25.36 & 51.31 & 23.33 \\
\hline
\end{tabular}

materials. The results in Table 1 also suggest that, as the concentrations of $\mathrm{Bi}^{3+}, \mathrm{Sb}^{3+}$, and $\mathrm{Te}^{4+}$ ions are close to each other, a Te-rich composition will be obtained in the deposited $(\mathrm{Bi}, \mathrm{Sb})_{2-x} \mathrm{Te}_{3+x}$ materials.

When larger negative voltage is used as bias in the potentiostatic deposition process, the electrolyte concentrations (or ion diffusion effect) will influence the composition of the deposited $(\mathrm{Bi}, \mathrm{Sb})_{2-x} \mathrm{Te}_{3+x}$-based materials. If we control the diffusion rates of ions $\left(\mathrm{Bi}^{3+}, \mathrm{Sb}^{3+}\right.$, and $\left.\mathrm{Te}^{4+}\right)$, we can regulate the composition of the deposited $(\mathrm{Bi}, \mathrm{Sb})_{2-x} \mathrm{Te}_{3+x^{-}}$ based materials. For that, the pulse deposition process is used to deposit $(\mathrm{Bi}, \mathrm{Sb})_{2-x} \mathrm{Te}_{3+x}$-based materials by using the electrolyte formula of $0.015 \mathrm{M} \mathrm{Bi}\left(\mathrm{NO}_{3}\right)_{3}-5 \mathrm{H}_{2} \mathrm{O}, 0.005 \mathrm{M}$ $\mathrm{SbCl}_{3}$, and $0.0075 \mathrm{M} \mathrm{TeCl}_{4}$. The bias voltage was set at $-0.40 \mathrm{~V}$, the duration of off time $\left(T_{\text {off }}\right)$ was changed from $0.1 \mathrm{~s}$ to $4 \mathrm{~s}$, and the bias on time $\left(T_{\text {on }}\right)$ was set at $0.2 \mathrm{~s}$. Table 2 first compares the results of the EDS analysis as a function of duration of $T_{\text {off }}$. As the duration of $T_{\text {off }}$ was $0.2 \mathrm{~s}$, the (Bi $+\mathrm{Sb}) / \mathrm{Te}$ atomic ratio was larger than $2 / 3$ (2/3 means close to $\left.(\mathrm{Bi}, \mathrm{Sb})_{2} \mathrm{Te}_{3}\right)$; as the duration of $T_{\text {off }}$ was in the range of
$0.4 \mathrm{~s} \sim 1 \mathrm{~s}$, the $(\mathrm{Bi}+\mathrm{Sb}) / \mathrm{Te}$ atomic ratio was close to $2 / 3$; as the duration of $T_{\text {off }}$ was longer than $1 \mathrm{~s}$, the Te atomic ratio was larger than $70 \%$.

Table 2 also compares the variation in the composition of the deposited $(\mathrm{Bi}, \mathrm{Sb})_{2-x} \mathrm{Te}_{3+x}$-based materials as the reduced voltage during the $T_{\text {on }}$ state was changed, where $T_{\text {on }}$ and $T_{\text {off }}$ were set at $0.2 \mathrm{~s}$ and $1 \mathrm{~s}$ and the pulse voltage was changed from $-0.3 \mathrm{~V}$ to $-0.6 \mathrm{~V}$. Also, $0.015 \mathrm{M} \mathrm{Bi}\left(\mathrm{NO}_{3}\right)_{3}$ $5 \mathrm{H}_{2} \mathrm{O}, 0.005 \mathrm{M} \mathrm{SbCl}_{3}$, and $0.0075 \mathrm{M} \mathrm{TeCl}_{4}$ were used as the electrolyte formula. As Table 2 shows, as the reduced voltage was in the range of $-0.3 \mathrm{~V}$ to $-0.6 \mathrm{~V}$, the atomic ratio of $(\mathrm{Bi}+\mathrm{Sb}) / \mathrm{Te}$ was close to $2 / 3$. As the reduced voltage was in the range of $-0.4 \mathrm{~V}$ to $-0.6 \mathrm{~V}$, the deposited $(\mathrm{Bi}, \mathrm{Sb})_{2-x} \mathrm{Te}_{3+x}$-based materials revealed the p-typed thermoelectric property, because the Te atomic ratio was smaller than $60 \%$. Those results prove that, as the mass transfer effect of $\mathrm{Te}^{4+}$ is controlled, the more $\mathrm{Bi}^{3+}$ and $\mathrm{Sb}^{3+}$ ions will be reduced into $\mathrm{Bi}$ and $\mathrm{Sb}$ and the composition of the deposited $(\mathrm{Bi}, \mathrm{Sb})_{2-x} \mathrm{Te}_{3+x}$-based materials will be close to p-typed $(\mathrm{BiSb})_{2} \mathrm{Te}_{3}$. Undoubtedly, the pulse deposition process can 


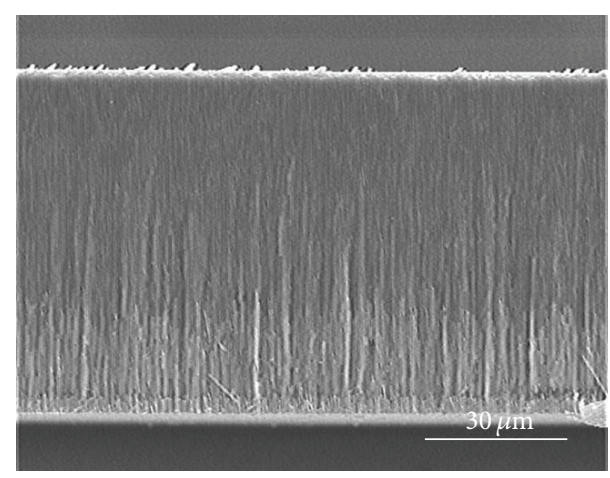

(a)

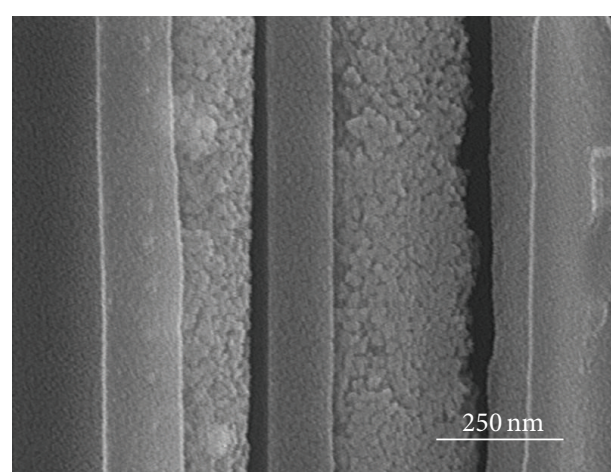

(b)

Figure 6: SEM micrographs of the $(\mathrm{Bi}, \mathrm{Sb})_{2-x} \mathrm{Te}_{3+x}$-based nanowires; the bias voltage was set at $-0.4 \mathrm{~V}, T_{\text {on }} / \mathrm{T}_{\text {off }}$ was $0.2 \mathrm{~s} / 0.6 \mathrm{~s}$, and the electrolyte formula was $0.015 \mathrm{M} \mathrm{Bi}\left(\mathrm{NO}_{3}\right)_{3}-5 \mathrm{H}_{2} \mathrm{O}, 0.005 \mathrm{M} \mathrm{SbCl}_{3}$, and $0.0075 \mathrm{M} \mathrm{TeCl}_{4}$. (a) Side view with smaller ratio and (b) side view with larger ratio.

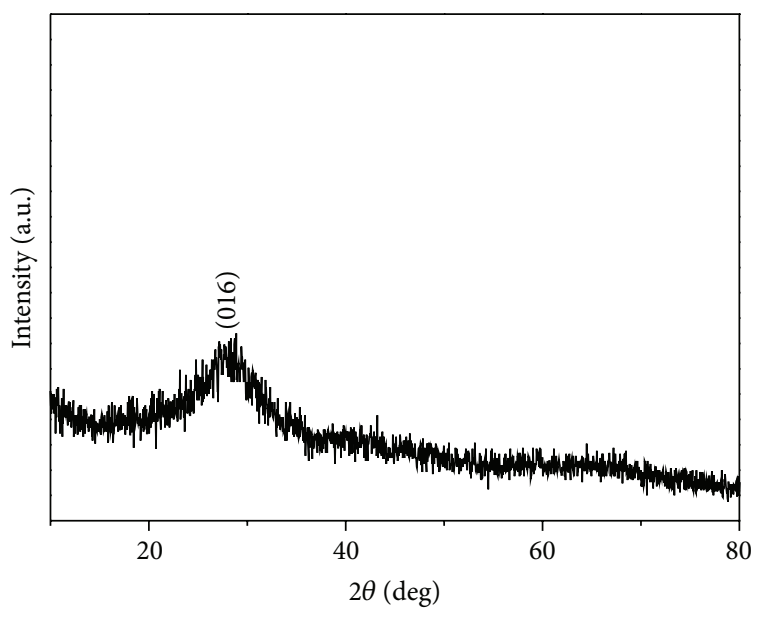

FIgURE 7: XRD pattern of the $(\mathrm{Bi}, \mathrm{Sb})_{2-x} \mathrm{Te}_{3+x}$-based nanowire.

control the composition of the deposited $(\mathrm{Bi}, \mathrm{Sb})_{2-x} \mathrm{Te}_{3+x^{-}}$ based materials.

Figure 5 shows the SEM micrographs of the electrolyte formula $0.015 \mathrm{M} \mathrm{Bi}\left(\mathrm{NO}_{3}\right)_{3}-5 \mathrm{H}_{2} \mathrm{O}, 0.005 \mathrm{M} \mathrm{SbCl}_{3}$, and $0.0075 \mathrm{M} \mathrm{TeCl}_{4}$ as a function of $T_{\text {off }}(0.1 \mathrm{~s} \sim 4 \mathrm{~s})$; the reduced voltage was set at $-0.4 \mathrm{~V}$ and $T_{\text {on }}$ was set at $0.2 \mathrm{~s}$. As $T_{\text {off }}$ was in the range of $0.1 \mathrm{~s} \sim 1 \mathrm{~s}$, as Figures 5(a)-5(c) show, the deposited (Bi, Sb) ${ }_{2-x} \mathrm{Te}_{3+x}$-based materials revealed a structure of nanoscale particles, which were aggregated together; as longer $T_{\text {off }}$ was used, as Figures 5(d)-5(f) show for $T_{\text {off }}$ in the range of $1.6 \mathrm{~s} \sim 4 \mathrm{~s}$, the deposited materials changed from nanoscale-aggregated particles to disk-typed particles. From the EDS analysis shown in Table 2, more Te in the deposited $(\mathrm{Bi}, \mathrm{Sb})_{2-x} \mathrm{Te}_{3+x}$-based materials is the reason to cause the variation in the morphology. Compared with the results in Table 2 and Figure 5, as $T_{\text {on }}$ is set at $0.2 \mathrm{~s}, T_{\text {off }}$ equal to or longer than $1 \mathrm{~s}$ is not suitable to deposit the $(\mathrm{Bi}, \mathrm{Sb})_{2-x} \mathrm{Te}_{3+x^{-}}$ based nanowires, because the main composition is Te and the pulse deposition process leads to large disk-typed particles.

Finally, the electrolyte formula of $0.015 \mathrm{M} \mathrm{Bi}\left(\mathrm{NO}_{3}\right)_{3}$ $5 \mathrm{H}_{2} \mathrm{O}, 0.005 \mathrm{M} \mathrm{SbCl}_{3}$, and $0.0075 \mathrm{M} \mathrm{TeCl}_{4}$ in the pulse deposition process was used to deposit the $(\mathrm{Bi}, \mathrm{Sb})_{2-x} \mathrm{Te}_{3+x^{-}}$ based nanowires. The AAO template used to deposit the $(\mathrm{Bi}, \mathrm{Sb})_{2-x} \mathrm{Te}_{3+x}$-based nanowires had the diameter of $120 \sim$ $270 \mathrm{~nm}$, as the deposited nanowires show in Figure 6. As the reduced voltage was $-0.4 \mathrm{~V}$, the $T_{\text {on }} / T_{\text {off }}$ was $0.2 \mathrm{~s} / 0.6 \mathrm{~s}$, and the cycle time was $10^{5}$; the $(\mathrm{Bi}, \mathrm{Sb})_{2-x} \mathrm{Te}_{3+x}$-based nanowires were successfully grown in AAO templates. The SEM picture for that the nanowires is shown in Figure 6(a), they had the length of $25 \sim 40 \mu \mathrm{m}$. The diameter of nanowires was dependent on that of AAO template, which was in the range of $120 \sim 270 \mathrm{~nm}$ as Figure 6(b) shows, and the atomic ratio for $\mathrm{Bi}: \mathrm{Sb}: \mathrm{Te}$ is $4.12: 32.05: 63.83$. XRD pattern of $(\mathrm{Bi}, \mathrm{Sb})_{2-x} \mathrm{Te}_{3+x}$-based nanowires is shown in Figure 7; the amorphous phase and (016) peak were observed. This result suggests that, as the AAO template and pulse deposition process are used to deposit the $(\mathrm{Bi}, \mathrm{Sb})_{2-x} \mathrm{Te}_{3+x}$-based nanowires, the $(\mathrm{Bi}, \mathrm{Sb})_{2-x} \mathrm{Te}_{3+x}$ phase can be formed. Figure 8 shows the EDS analysis of the $(\mathrm{Bi}, \mathrm{Sb})_{2-x} \mathrm{Te}_{3+x}$-based nanowires; the photos show that the detective intensity of Te is higher than those of $\mathrm{Bi}$ and $\mathrm{Te}$, which match the results shown in Table 2.

\section{Conclusions}

When pulse deposition process was used, the $T_{\text {on }} / T_{\text {off }}$ ratio and the reduced voltage would influence the composition of the $(\mathrm{Bi}, \mathrm{Sb})_{2-x} \mathrm{Te}_{3+x}$-based materials. As the duration of $T_{\text {off }}$ was in the range of $0.4 \mathrm{~s} \sim 1 \mathrm{~s}$, the $(\mathrm{Bi}+\mathrm{Sb}) / \mathrm{Te}$ atomic ratio was close to $2 / 3$; as the duration of $T_{\text {off }}$ was longer than $1 \mathrm{~s}$, the Te atomic ratio was larger than $70 \%$. As $T_{\text {on }}$ and $T_{\text {off }}$ were set at $0.2 \mathrm{~s}$ and $1 \mathrm{~s}$, and the pulse voltage was changed from $-0.4 \mathrm{~V}$ to $-0.6 \mathrm{~V}$, the deposited $(\mathrm{Bi}, \mathrm{Sb})_{2-x} \mathrm{Te}_{3+x}$-based materials revealed the p-typed thermoelectric property, because the Te atomic ratio was smaller than $60 \%$. As the reduced voltage was $-0.4 \mathrm{~V}$ and the $T_{\text {on }} / T_{\text {off }}$ was $0.2 \mathrm{~s} / 0.6 \mathrm{~s}$, the $(\mathrm{Bi}, \mathrm{Sb})_{2-x} \mathrm{Te}_{3+x}$-based nanowires were successfully grown in AAO templates. The nanowires had the length of $25 \sim 40 \mu \mathrm{m}$ and the diameter of $120 \sim 270 \mathrm{~nm}$, and the atomic ratio for $\mathrm{Bi}: \mathrm{Sb}: \mathrm{Te}$ was $4.12: 32.05: 63.83$. 

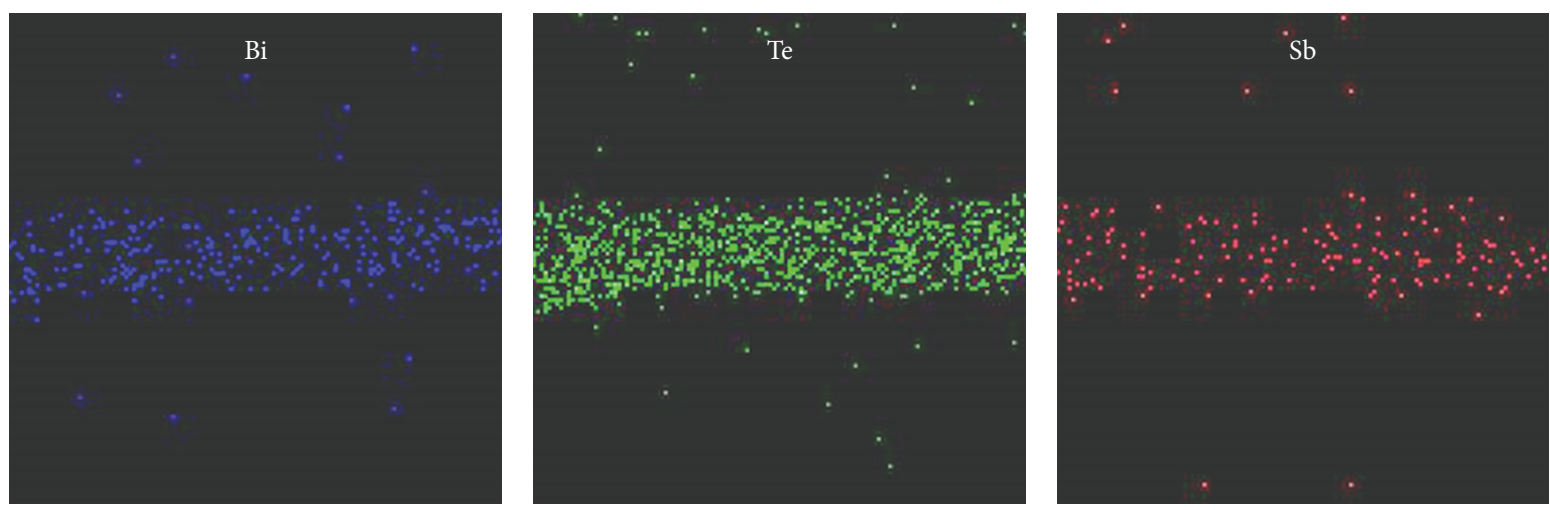

FIgURE 8: EDS analysis of the $(\mathrm{Bi}, \mathrm{Sb})_{2-x} \mathrm{Te}_{3+x}$-based nanowire.

\section{Conflict of Interests}

The authors declare that there is no conflict of interests regarding the publication of this paper.

\section{Acknowledgments}

The authors acknowledge the financial support of NSC 1023113-S-003-008-G, NSC 102-3113-S-262-001, NSC 102-2221-E218-036, and NSC 102-2221-E-390-027.

\section{References}

[1] G. Mahan, B. Sales, and J. Sharp, "Thermoelectric materials: new approaches to an old problem," Physics Today, vol. 50, no. 3, pp. 42-47, 1997.

[2] J. Y. Hwang, H. Mun, J. Y. Cho et al., "Electronic and thermal transport properties of complex structured $\mathrm{Cu}-\mathrm{Bi}$-Se thermoelectric compound with low lattice thermal conductivity," Journal of Nanomaterials, vol. 2013, Article ID 502150, 7 pages, 2013.

[3] A. I. Boukai, Y. Bunimovich, J. Tahir-Kheli, J. Yu, W. A. Goddard III, and J. R. Heath, "Silicon nanowires as efficient thermoelectric materials," Nature, vol. 451, no. 7175, pp. 168-171, 2008.

[4] K. F. Hsu, S. Loo, F. Guo et al., "Cubic $\mathrm{AgPb}_{m} \mathrm{SbTe}_{2+m}$ : bulk thermoelectric materials with high figure of merit," Science, vol. 303, no. 5659, pp. 818-821, 2004.

[5] K. Kadel, L. Kumari, W. Z. Li, J. Y. Huang, and P. P. Provencio, "Synthesis and thermoelectric properties of $\mathrm{Bi}_{2} \mathrm{Se}_{3}$ nanostructures," Nanoscale Research Letters, vol. 6, no. 1, article 57, 2011.

[6] D. M. T. Kuo and Y. C. Chang, "Effects of interdot hopping and Coulomb blockade on the thermoelectric properties of serially coupled quantum dots," Nanoscale Research Letters, vol. 7, article 257, 2012.

[7] P. Slobodian, P. Riha, R. Olejnik, M. Kovar, and P. Svoboda, "Thermoelectric properties of carbon nanotube and nanofiber based ethylene-octene copolymer composites for thermoelectric devices," Journal of Nanomaterials, vol. 2013, Article ID 792875, 7 pages, 2013.

[8] L. D. Hicks and M. S. Dresselhaus, "Effect of quantum-well structures on the thermoelectric figure of merit," Physical Review B, vol. 47, no. 19, pp. 12727-12731, 1993.
[9] Z. Fan, J. Zheng, H. Q. Wang, and J. C. Zheng, "Enhanced thermoelectric performance in three-dimensional superlattice of topological insulator thin films," Nanoscale Research Letters, vol. 7, article 570, 2012.

[10] R. Venkatasubramanian, E. Siivola, T. Colpitts, and B. O’Quinn, "Thin-film thermoelectric devices with high room-temperature figures of merit," Nature, vol. 413, no. 6856, pp. 597-602, 2001.

[11] T. C. Harman, P. J. Taylor, M. P. Walsh, and B. E. LaForge, "Quantum dot superlattice thermoelectric materials and devices," Science, vol. 297, no. 5590, pp. 2229-2232, 2002.

[12] Y. Jia, D. Yang, B. Luo, S. Liu, M. O. Tade, and L. Zhi, "One-pot synthesis of Bi-Ni nanowire and nanocable arrays by coelectrodeposition approach," Nanoscale Research Letters, vol. 7, article 130, 2012.

[13] T. C. Harman, P. J. Taylor, D. L. Spears, and M. P. Walsh, “Thermoelectric quantum-dot superlattices with high ZT," Journal of Electronic Materials, vol. 29, no. 1, pp. L1-L2, 2000.

[14] D. Li, Y. Wu, R. Fan, P. Yang, and A. Majumdar, "Thermal conductivity of $\mathrm{Si} / \mathrm{SiGe}$ superlattice nanowires," Applied Physics Letters, vol. 83, no. 15, pp. 3186-3188, 2003.

[15] Y. Li, J. Wang, Z. Deng et al., "Bismuth nanotubes: a rational low-temperature synthetic route," Journal of the American Chemical Society, vol. 123, no. 40, pp. 9904-9905, 2001.

[16] F. Xiao, C. Hangarter, B. Yoo, Y. Rheem, K. Lee, and N. V. Myung, "Recent progress in electrodeposition of thermoelectric thin films and nanostructures," Electrochimica Acta, vol. 53, no. 28, pp. 8103-8117, 2008.

[17] R. J. Mehta, Y. Zhang, C. Karthik et al., "A new class of doped nanobulk high-figure-of-merit thermoelectrics by scalable bottom-up assembly," Nature Materials, vol. 11, no. 3, pp. 233-240, 2012.

[18] K. T. Kim and G. H. Ha, "Fabrication and enhanced thermoelectric properties of alumina nanoparticle-dispersed $\mathrm{Bi}_{0.5} \mathrm{Sb}_{1.5} \mathrm{Te}_{3}$ matrix composites," Journal of Nanomaterials, vol. 2013, Article ID 821657, 6 pages, 2013.

[19] H. Masuda and K. Fukuda, "Ordered metal nanohole arrays made by a two-step replication of honeycomb structures of anodic alumina," Science, vol. 268, no. 5216, pp. 1466-1468, 1995.

[20] T. Fang, T. H. Wang, S. Kang, and C. Chuang, "Indentation deformation of mesoporous anodic aluminum oxide," Current Applied Physics, vol. 9, no. 4, pp. 880-883, 2009.

[21] M. S. Chandrasekar and M. Pushpavanam, "Pulse and pulse reverse plating-Conceptual, advantages and applications," Electrochimica Acta, vol. 53, no. 8, pp. 3313-3322, 2008. 

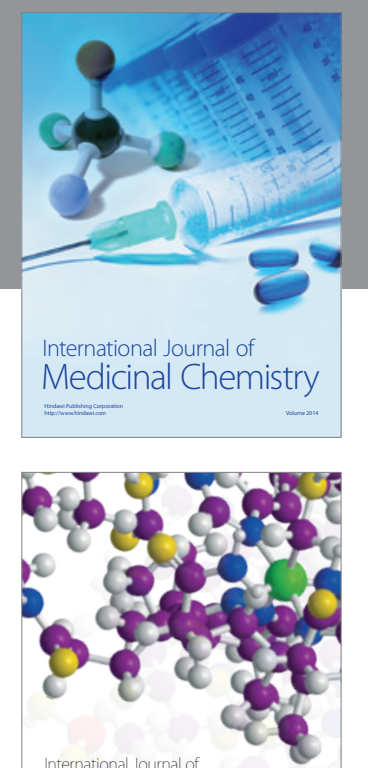

\section{Carbohydrate} Chemistry

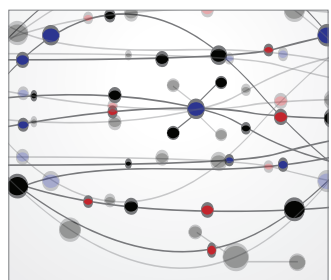

The Scientific World Journal
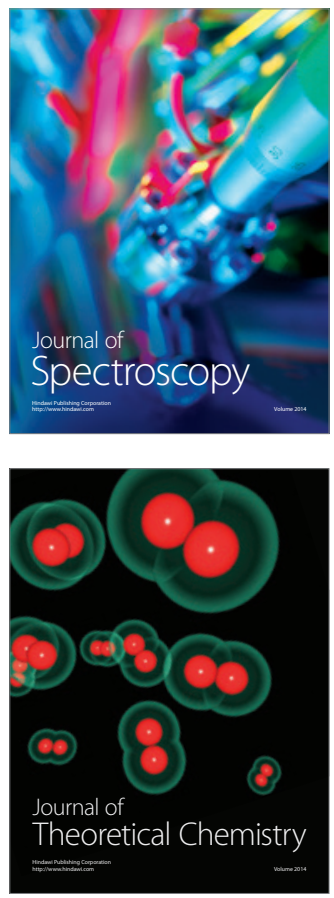
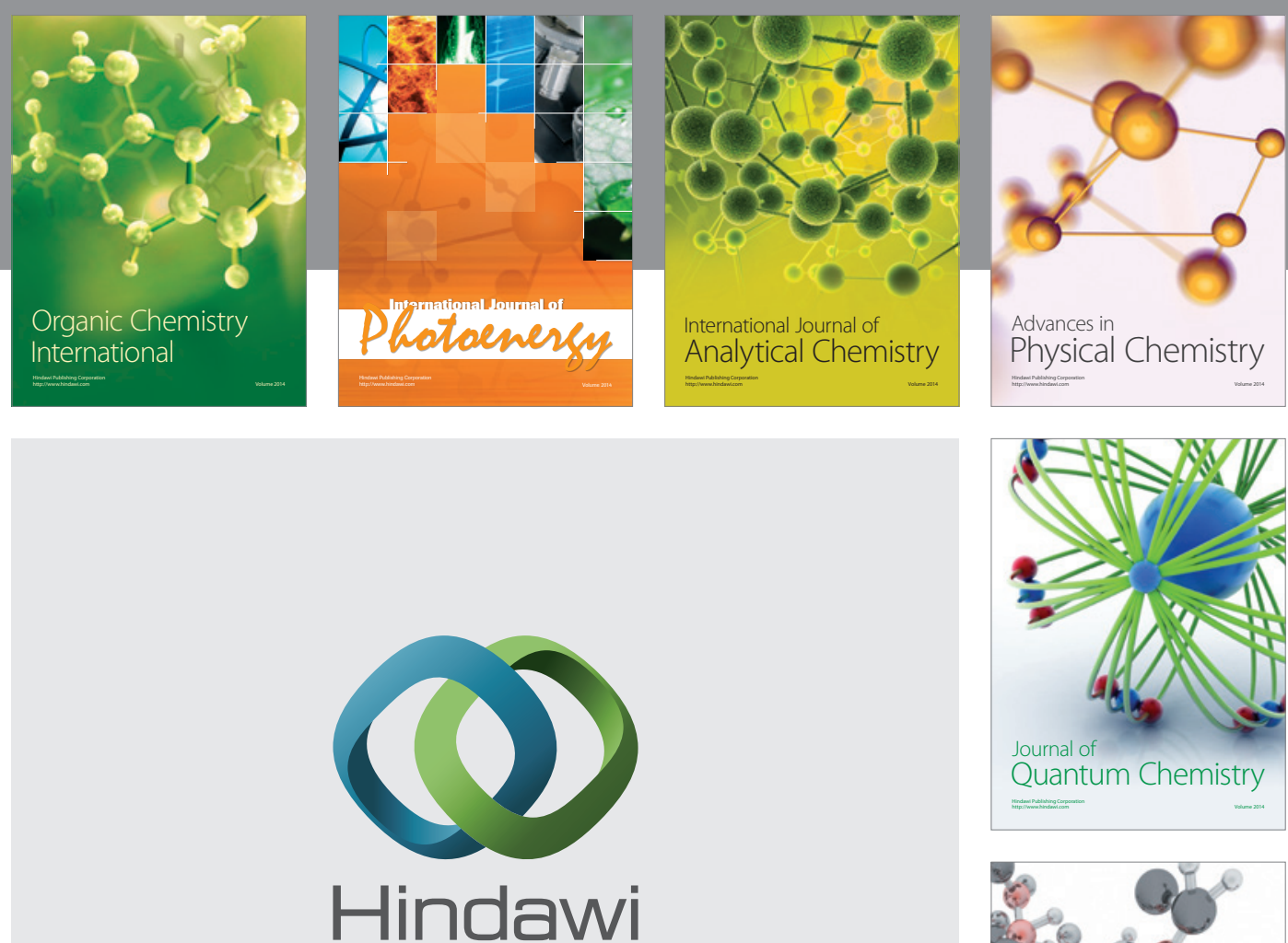

Submit your manuscripts at

http://www.hindawi.com

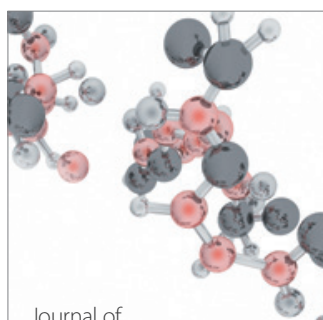

Analytical Methods

in Chemistry

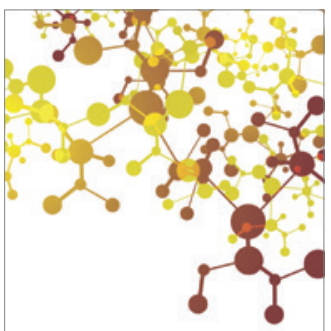

Journal of

Applied Chemistry

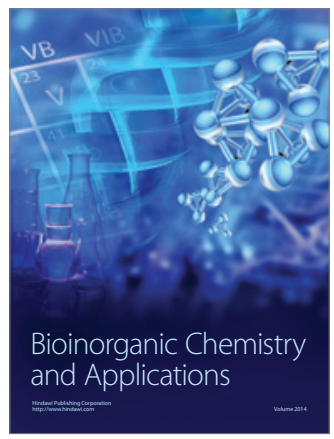

Inorganic Chemistry
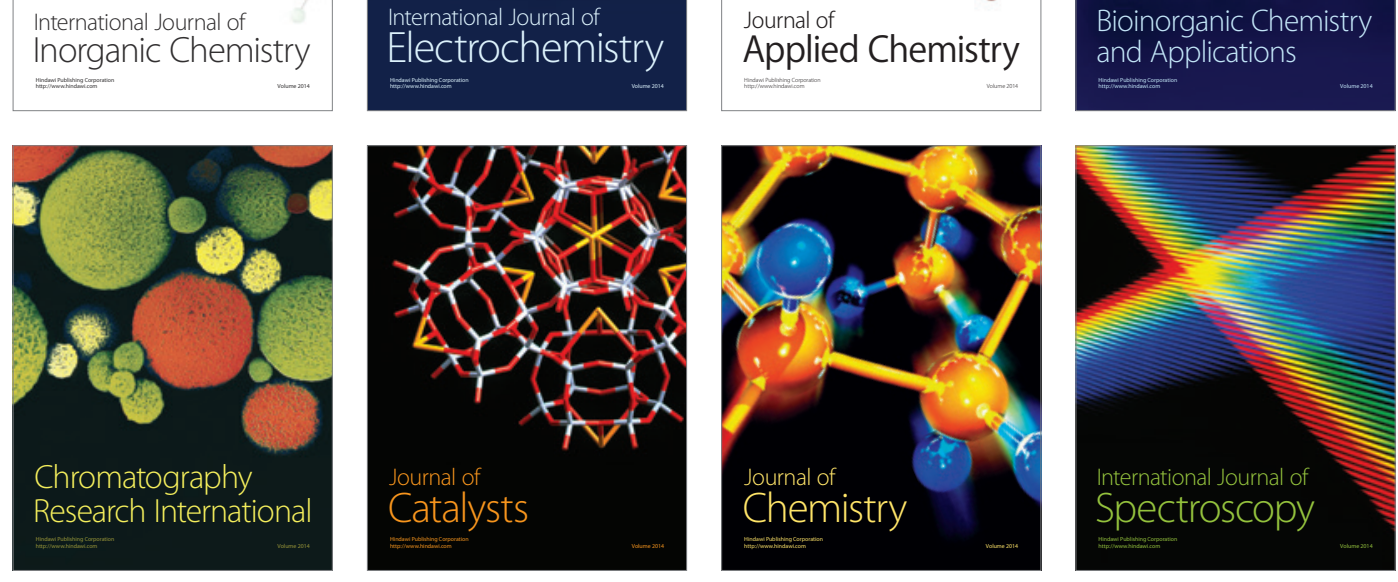